\title{
Study of Direct Bonding of Ceramic and Metallic Materials with Zn4Al Solder
}

\section{Roman Koleňák, Igor Kostolný}

Slovak University of Technology in Bratislava, Faculty of Materials Science and Technology in Trnava, Paulínska 16, 91724 Trnava, Slovak Republic roman.kolenak@stuba.sk,igor.kostolny@stuba.sk

Abstract: The aim of this work was to evaluate the direct bonding of Al2O3, SiC ceramics and $\mathrm{Cu}$ substrates. Joints were fabricated by using $40 \mathrm{kHz}$ frequency ultrasound. The $\mathrm{Zn} 4 \mathrm{Al}$ solder wetted all materials studied and joints of good quality were produced. The shear strength attained with Al2O3 ceramics was $81 \mathrm{MPa}$. The strength with SiC ceramics was slightly lower at $65 \mathrm{MPa}$. In a copper substrate, we observed shear strengths of $84 \mathrm{MPa}$.

Keywords: soldering; ceramic; metallic; microstructure; strength

\section{Introduction}

Zn-based solders belong to the group of solders applicable for higher application temperatures. Currently, soldering technology at these temperatures is widely used and imparts irreplaceable properties to the resulting product for high thermal conductivity and reliability. These solders are mainly used in electronics, as well as, in the automotive, space, aviation and power industries.

In the study [1], we investigated the direct bonding of $\mathrm{SiC}$ ceramics with ultrasound assistance. The ceramic SiC substrates were soldered in the air with $\mathrm{Zn} 8.5 \mathrm{AllMg}$ solder at a temperature of $420^{\circ} \mathrm{C}$. The shear strength of joints increased with longer periods of ultrasound exposure. The highest strength (148.1 $\mathrm{MPa}$ ) was achieved at ultrasound periods lasting for $8 \mathrm{~s}$. A new amorphous layer 2 to $6 \mathrm{~nm}$ thick was formed on the boundary between the solder and substrate. The atoms from eroded $\mathrm{SiO}_{2}$ layers from $\mathrm{SiC}$ substrates quickly diffused to the solder, owing to the jet effect caused by ultrasound. The strong bond between SiC substrate and $\mathrm{Zn}-\mathrm{Al}-\mathrm{Mg}$ solder is attributed to the transfer of $\mathrm{SiO}_{2}$ mass to $\mathrm{Zn}-\mathrm{Al}$ $\mathrm{Mg}$ solder by induced cavitation erosion.

Direct bonding of sapphire (a crystalline form of $\mathrm{Al}_{2} \mathrm{O}_{3}$ ) by ultrasound, with the application of Sn10Zn2Al solder was the subject of a study [2]. It was found that ultrasound supported the oxidation reaction between $\mathrm{Al}$ from the solder and 
sapphire substrate. A nano-crystalline $\alpha-\mathrm{Al}_{2} \mathrm{O}_{3}$ layer ( $2 \mathrm{~nm}$ thick) was formed in the $\mathrm{Sn}-\mathrm{Zn}-\mathrm{Al} / \mathrm{sapphire}$ boundary during soldering in the air at a temperature of $230^{\circ} \mathrm{C}$. The shear strength of joints measured 43 to $48 \mathrm{MPa}$, which is a relatively high value when compared to other $\mathrm{Al}_{2} \mathrm{O}_{3}$ ceramic joints fabricated with active $\mathrm{Sn}$ solders and the addition of $\mathrm{Ti}$ and/or lanthanides $[3,4,5]$.

The aim of our work was to study the direct bonding of $\mathrm{Al}_{2} \mathrm{O}_{3}, \mathrm{SiC}$ ceramics and copper substrate. Contrary to previous studies, the close-to-eutectic solder based on $\mathrm{Zn}-\mathrm{Al}$, (actually $\mathrm{Zn} 4 \mathrm{Al}$ ) was used. This solder is used for fluxless soldering of aluminum and its alloys. Ultrasonic soldering with direct ultrasound action was employed through the layer of molten solder.

\section{Experimental}

$\mathrm{Zn}$ solder with $4 \mathrm{wt} \%$ of $\mathrm{Al}$ was used in the experiments. The solder was manufactured in cast state in a high vacuum of $10^{-4} \mathrm{~Pa}$. The procedure was as follows: the calculated charges of alloy components were inserted into a graphite boat. The boat with the charge was placed into a horizontal tube resistance vacuum furnace so that the boat was situated in the heating zone. The tube could be flushed with Ar, owing to a flange on its edge and an outlet on its end.

For $\mathrm{Zn}$-based solders it is more suitable to prepare them in overpressure of Ar, due to evaporation. The charge was exposed to temperature above $450^{\circ} \mathrm{C}$. Homogenization of individual components took place at this temperature.

Experiments used the substrates of the following materials:

- Metallic substrate of $\mathrm{Cu}$ with $4 \mathrm{~N}$ purity in the form of rings, in dimensions $\varnothing 15 \times 1.5 \mathrm{~mm}$

- Ceramic $\mathrm{Al}_{2} \mathrm{O}_{3}$ substrate, with $2 \mathrm{~N} 5$ purity in the form of $\varnothing 15 \times 2 \mathrm{~mm}$ rings (manufacturer Glynwed, $\mathrm{GmbH}$, designation Degussit Al23),

- Ceramic $\mathrm{SiC}$ substrate in the form of $\varnothing 15 \times 3 \mathrm{~mm}$ rings (manufacturer CeramTec, $\mathrm{GmbH}$, des. Rocar $\left.{ }^{\circledR} \mathrm{SiC}\right)$.

The combinations of materials shown in Fig. 1 were used for more detailed analysis.
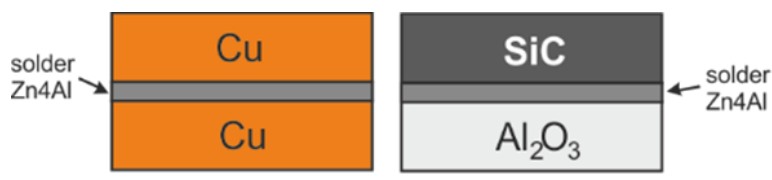

Figure 1

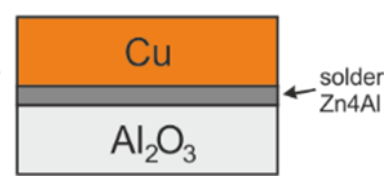

$\mathrm{Al}_{2} \mathrm{O}_{3}$

Analyzed combinations of $\mathrm{Cu} / \mathrm{Cu}, \mathrm{SiC}_{\mathrm{Al}} \mathrm{O}_{3}$ and $\mathrm{Cu} / \mathrm{Al}_{2} \mathrm{O}_{3}$ materials 
Soldering was performed by Hanuz UT2 ultrasonic equipment with the parameters given in Table 1. The solder was activated by use of an encapsulated ultrasonic transducer consisting of a piezo-electric oscillating system and a titanium sonotrode with an $\varnothing 3 \mathrm{~mm}$ end diameter. The scheme of ultrasonic soldering through the layer of molten solder is shown in Fig. 2. The soldering temperature was $20^{\circ} \mathrm{C}$ above the liquid temperature of the solder. Soldering temperature was checked by a continuous temperature measurement on the hot plate, using a $\mathrm{NiCr} / \mathrm{NiSi}$ thermocouple.

Table 1

Soldering parameters

\begin{tabular}{|l|c|c|}
\hline Ultrasound power & {$[\mathrm{W}]$} & 400 \\
\hline Working frequency & {$[\mathrm{kHz}]$} & 40 \\
\hline Amplitude & {$[\mu \mathrm{m}]$} & 2 \\
\hline Soldering temperature & {$\left[{ }^{\circ} \mathrm{C}\right]$} & $415^{\circ} \mathrm{C}$ \\
\hline Time of ultrasound activation & {$[\mathrm{s}]$} & 5 \\
\hline
\end{tabular}

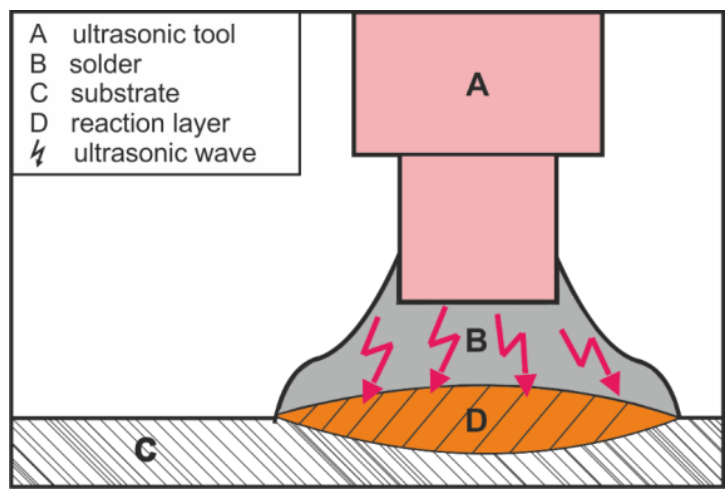

Figure 2

Ultrasonic soldering through the layer of molten solder

Soldering procedures took place in with the substrate heated at the soldering temperature deposited with a solder layer. Active ultrasound then acts upon the molten solder in the air without use of protective atmosphere for $5 \mathrm{~s}$. After ultrasonic activation, the excessive layer of molten solder and the formed oxides are removed from the substrate surface. Both soldered substrates were prepared in the same way. The substrates with a deposited layer of molten solder were applied to each other so as to maintain contact during the molten phase. This assembly is then centered and the desired joint is achieved by slight compression. A graphic illustration of this procedure is shown in Fig. 3. 


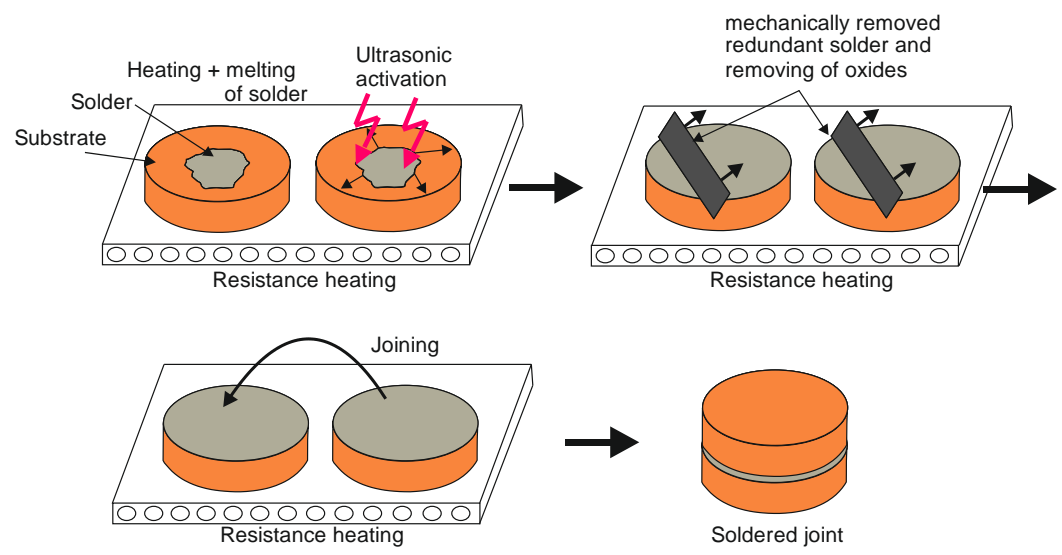

Figure 3

Procedure of joint fabrication by ultrasonic soldering

Metallographic preparation of specimens from the soldered joints was achieved by standard metallographic procedures used for preparation of specimens. The SiC emery papers with a granularity of 240, 320 and 1200 grains $/ \mathrm{cm}^{2}$ were used for grinding. The polishing was done by use of diamond suspensions with grain sizes: $9 \mu \mathrm{m}, 6 \mu \mathrm{m}$ and $3 \mu \mathrm{m}$. The final polishing was done using a type OP-S (Struers)polishing emulsion with a granularity of $0.2 \mu \mathrm{m}$.

Solder microstructure was observed by the aid of following:

- Neophot 32 light optical microscope, supplemented by a NIS-Elements, type E image analyzer

- Qualitative and semi-qualitative chemical analysis of the solder was performed by JEOL 7600 F equipment with a Microspec WDX-3PC Xray micro-analyzer

$\mathrm{X}$-ray diffraction analysis was used to identify the phase composition of the solder. It was applied on 10 x $10 \mathrm{~mm}$ solder specimens using a PANalyticalX'Pert PRO XRD diffractometer.

The DSC analysis of Zn4Al solder was performed on Netzsch STA 409 C/CD equipment in the Ar shielding gas with $6 \mathrm{~N}$ purity.

A shear test was carried out to determine the shear strength of joints. Measurements were done on two ceramic $\left(\mathrm{Al}_{2} \mathrm{O}_{3}\right.$ a $\left.\mathrm{SiC}\right)$ and five metallic materials (Al, Ni, Ti, Cr-Ni steel, Cu) soldered using $\mathrm{Zn} 4 \mathrm{Al}$ solder. The shear strength was determined on the versatile LabTest 5.250SP1-VM equipment. A shearing jig was used to change the direction of axial loading forces acting on the test specimen. This shearing jig ensured a uniform loading of specimens by shear in the plane of solder and substrate boundary (Fig. 4). The dwell time on soldering temperature during specimen fabrication was $30 \mathrm{~s}$ and the time of ultrasound acting was $5 \mathrm{~s}$. 

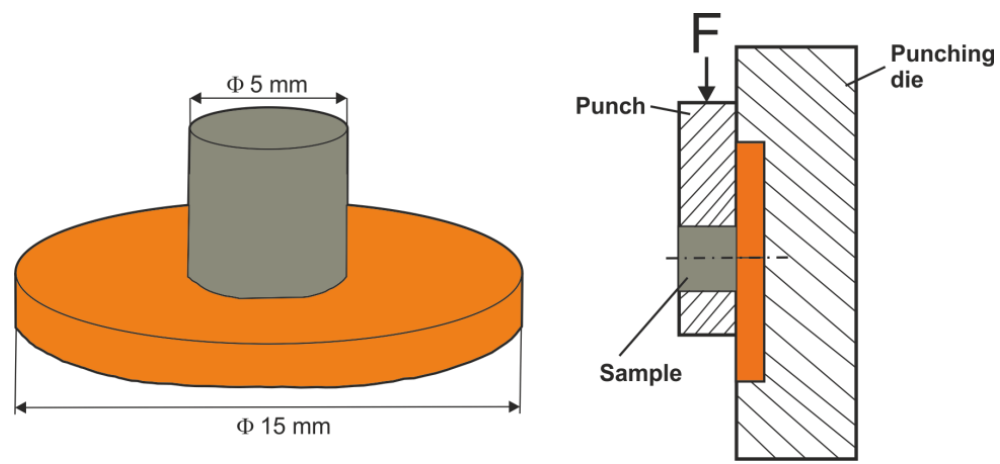

Figure 4

Test specimen for shear test and the scheme of specimen in the jig during the shear strength test [6]

\section{Experimental Results}

\section{Analysis of ZnAl4 solder}

Two solid solutions ( $\mathrm{Zn})$ and (Al) with a limited solubility occur in the binary AlZn system (Fig. 5). Owing to limited solubility, the eutecticum and eutectoid mixture of these solid solutions occurred in the system.

The matrix of $\mathrm{Zn} 4 \mathrm{Al}$ solder (Fig. 6) was composed of great grains of the solid solution ( $\mathrm{Zn}$ ) with concentration of $98.68 \mathrm{wt} \% \mathrm{Zn}$. A fine eutecticum, formed of solid solutions $(\mathrm{Zn})+(\mathrm{Al})$ was segregated along the grain boundaries. The quantitative analysis of solder is given below in Fig. 6 .

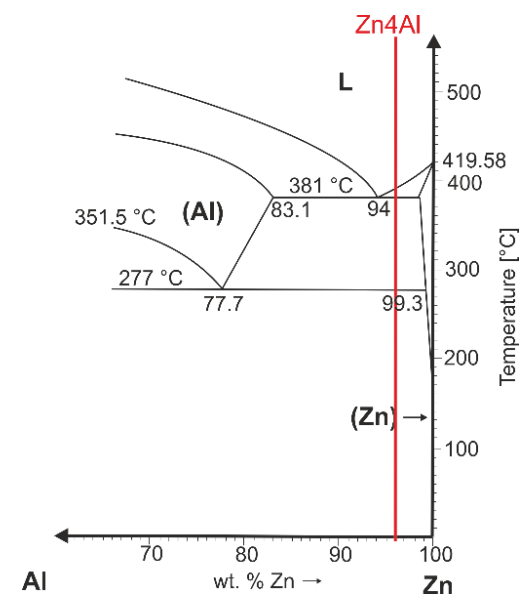

Figure 5

Binary Al-Zn diagram [7] 


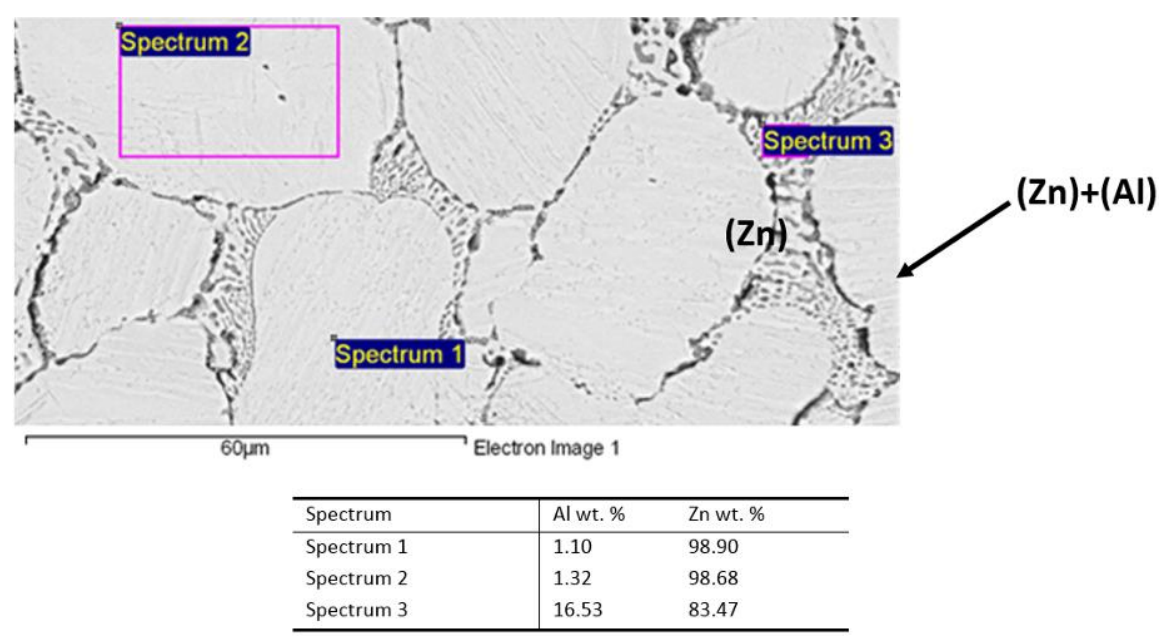

Figure 6

Microstructure of $\mathrm{Zn} 4 \mathrm{Al}$ solder

The ZnAl4 solder shows a narrower fusion interval, while it is of close-to eutectic composition. By the DSC analysis (Fig. 7a), a temperature of $277.6^{\circ} \mathrm{C}$ starts the onset of eutectoid transformation. The following reaction takes place at this temperature: Alrichfcc + hcp $(\mathrm{Zn}) / \mathrm{Zn}$-richfcc. The eutectic $(\mathrm{Zn}+6 \mathrm{wt}$ \% $\mathrm{Al})$, segregated along the grain boundaries of $\mathrm{Zn}$ matrix of the solder starts to melt at $380.7^{\circ} \mathrm{C}$. The solid solution $(\mathrm{Zn})$ attains its fully liquid state at $385.9^{\circ} \mathrm{C}-\mathrm{Fig} .7 \mathrm{~b}$.

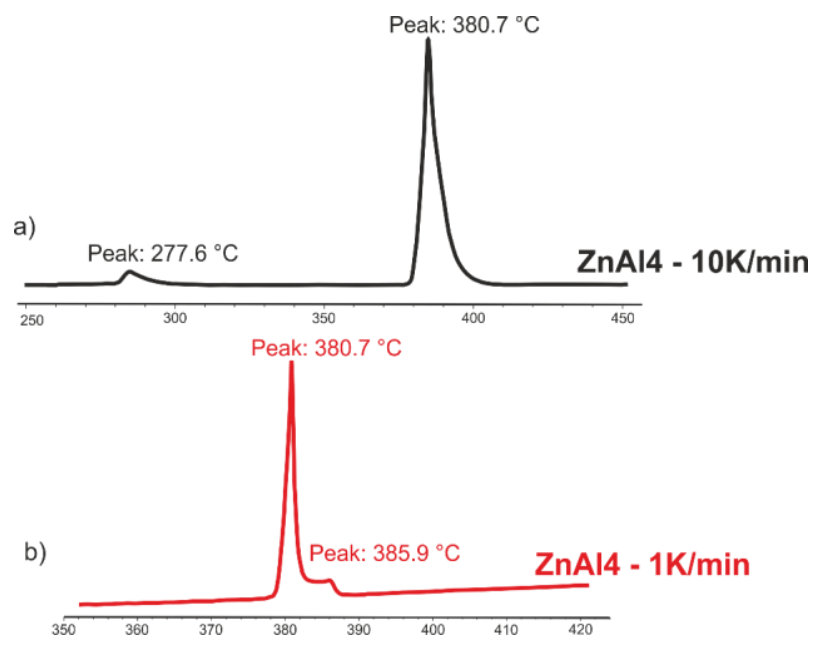

Figure 7

DSC analysis of $\mathrm{Zn}-4 \mathrm{Al}$ solder at heating rate: a) $10 \mathrm{~K} / \mathrm{min}$ b) $1 \mathrm{~K} / \mathrm{min}$ 
Mechanical tests of type $\mathrm{Zn}-\mathrm{Al}$ solders were performed. The dimensions of test pieces were designed and calculated. Fig. 8 shows the dimensions of test specimens and the actual test piece. Three pieces for each type of alloy were used for experimental assessment. The results of tensile strength tests of soldered type $\mathrm{Zn}-\mathrm{Al}$ alloys are documented in Fig. 9.

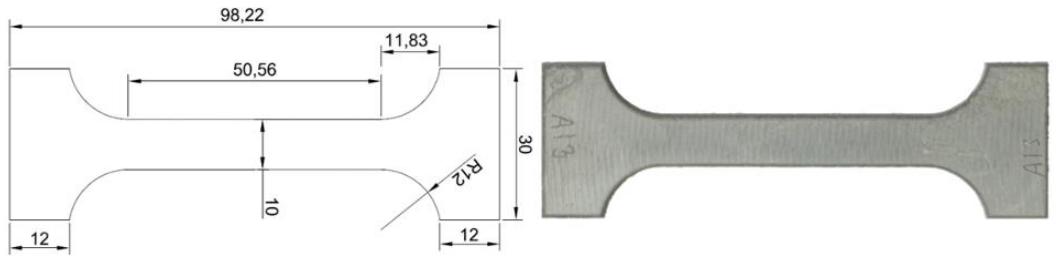

Figure 8

Dimensions of test specimen and a real view on a specimen of $\mathrm{Zn} 4 \mathrm{Al}$ solder

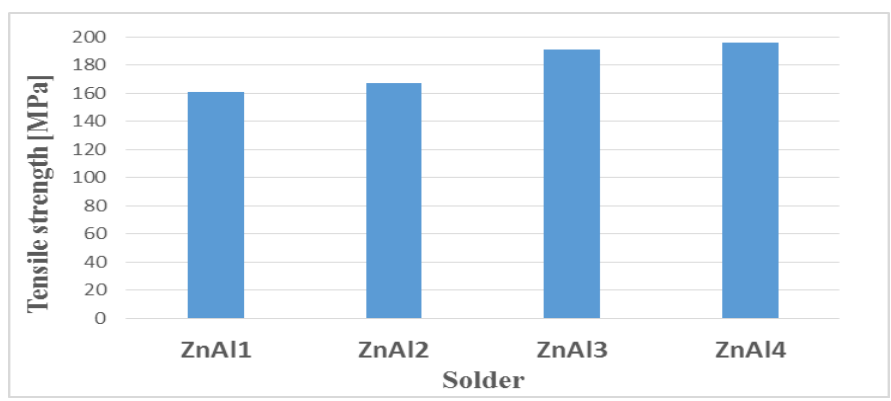

Figure 9

Tensile strength of soldered alloys type $\mathrm{Zn}-\mathrm{Al}$ in dependence on $\mathrm{Al}$ content

Generally, Al content slightly increases the strength of $\mathrm{Zn}-\mathrm{Al}$ solder. By increasing $\mathrm{Al}$ content, the strength of $\mathrm{Zn}-\mathrm{Al}$ solder increases - Fig. 15. The variance in tensile strength between $\mathrm{ZnAll}$ and $\mathrm{ZnAl} 4$ solder is around $35 \mathrm{MPa}$.

\section{Analysis of Joints in $\mathrm{Al}_{2} \mathrm{O}_{3}$ and $\mathrm{SiC}$ Ceramic Materials Soldered with $\mathrm{Zn4Al}$}

Fig. 10 shows the difference in the transition zone of $\mathrm{Al}_{2} \mathrm{O}_{3} / \mathrm{Zn} 4 \mathrm{Al}$ and $\mathrm{SiC} / \mathrm{Zn} 4 \mathrm{Al}$ joints. A wide transition zone up to $70 \mu \mathrm{m}$ in width was formed on the boundary with $\mathrm{SiC}$, where an increased amount, mainly of carbidic and silicon particles, was identified. Due to ultrasound erosion, the solder penetrated the grains of the ceramic materials and carbidic particles from ceramics and silicon particles, infiltrated in the grain boundaries of $\mathrm{SiC}$ ceramics and displaced into the solder. The concentration profiles in the SiC/Zn4Al boundary zone are shown in Fig. 11.

No distinct transition layer is observable in the boundary with $\mathrm{Al}_{2} \mathrm{O}_{3}$ ceramics Fig. 10b. The character of solder matrix in this boundary remains unchanged. No new transition phases were identified. The bond with $\mathrm{Al}_{2} \mathrm{O}_{3}$ ceramics is formed by solder adhesion with $\mathrm{Al}_{2} \mathrm{O}_{3}$ ceramics. 

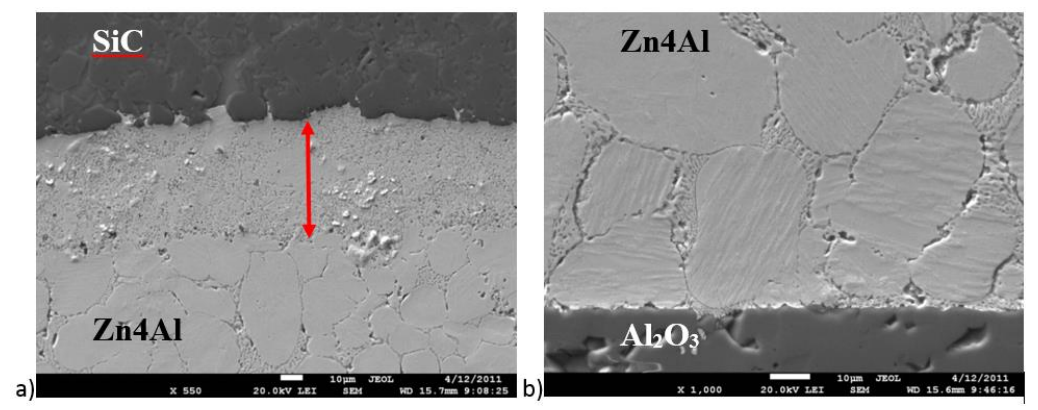

Figure 10

Microstructure in the boundary of a) $\mathrm{SiC} / \mathrm{Zn} 4 \mathrm{Al}$, b) $\mathrm{Al}_{2} \mathrm{O}_{3} / \mathrm{Zn} 4 \mathrm{Al}$ bonds
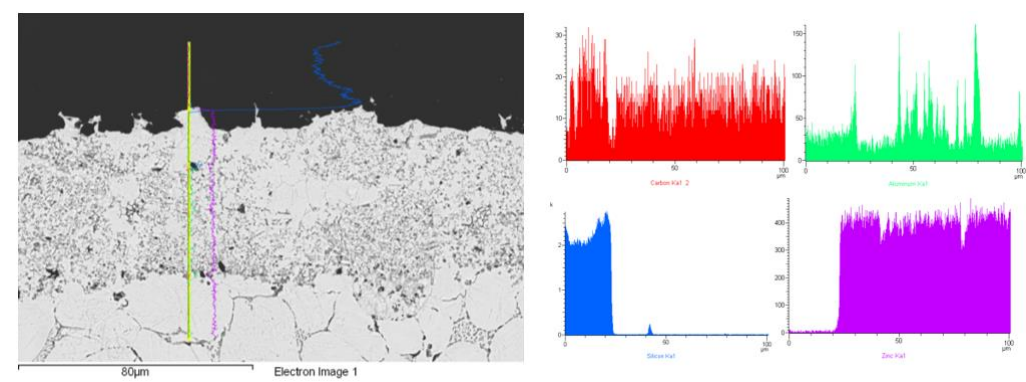

Figure 11

Microstructure in the boundary of $\mathrm{SiC} / \mathrm{Zn} 4 \mathrm{Al}$ bond and the concentration profiles of $\mathrm{C}, \mathrm{Al}, \mathrm{Si}$ and $\mathrm{Zn}$ elements

\section{Analysis of Bond between $\mathrm{Cu}$ and $\mathrm{Zn} 4 \mathrm{Al}$ Solder}

A wide zone of two new intermetallic phases was formed in the boundary of the $\mathrm{Cu} / \mathrm{Zn} 4 \mathrm{Al} / \mathrm{Cu}$ bond (Fig. 12). The $\mathrm{CuZn}_{4}$ and $\mathrm{Cu}_{5} \mathrm{Zn}_{8}$ phases were identified. The concentration profiles of $\mathrm{Cu}, \mathrm{Zn}$ and $\mathrm{Al}$ elements are shown in Fig. 13.

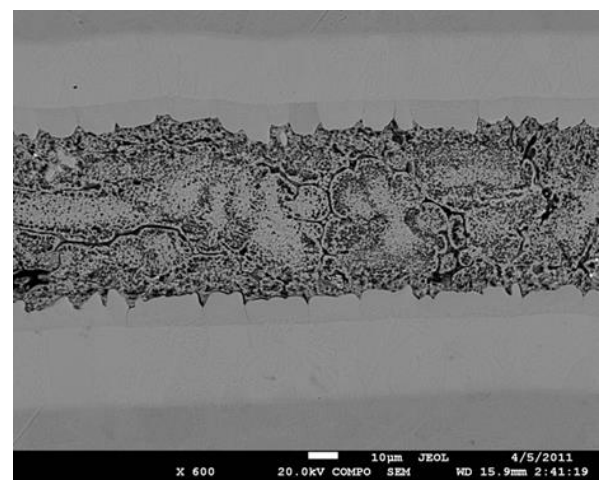

Figure 12

Microstructure of $\mathrm{Cu} / \mathrm{Zn} 4 \mathrm{Al} / \mathrm{Cu}$ bond boundary 

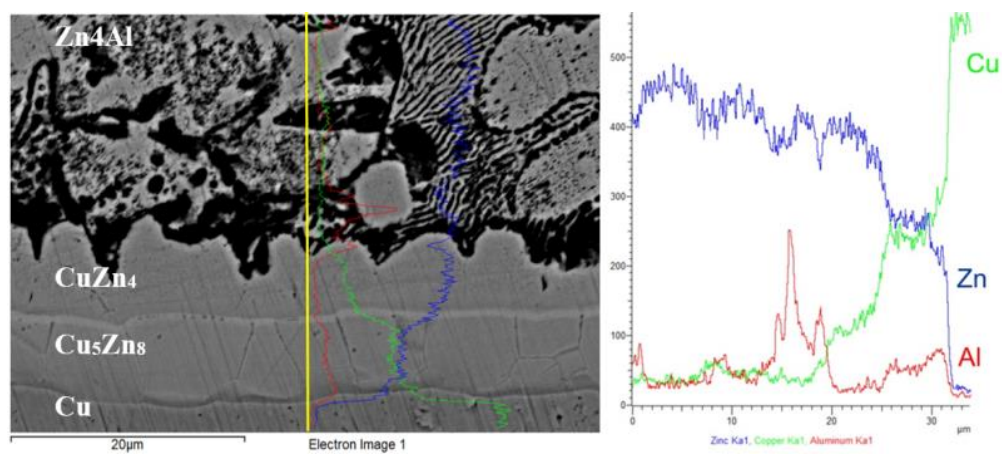

Figure 13

Line $\mathrm{EDX}$ analysis of $\mathrm{Cu} / \mathrm{Zn} 4 \mathrm{Al}$ soldered joint and concentration profiles of $\mathrm{Cu}, \mathrm{Zn}, \mathrm{Al}$ elements in $\mathrm{Cu} / \mathrm{Zn} 4 \mathrm{Al}$ boundary

\section{The Results of Shear Strength of Soldered Joints}

Research within this study was primary oriented toward soldering $\mathrm{Al}_{2} \mathrm{O}_{3}$ and $\mathrm{SiC}$ ceramic substrates and $\mathrm{Cu}$ substrates. The experiments to determine the shear strength of soldered joints were also extended to other metallic materials such as $\mathrm{Al}, \mathrm{Ni}, \mathrm{Ti}$ and $\mathrm{CrNi}$ steel, in order to prove the wider applicability of $\mathrm{Zn} 4 \mathrm{Al}$ solder.

Measurement was performed on 4 specimens of each material. The results of average shear strength of joints are documented in Fig. 14. The shear strength of $\mathrm{Al}_{2} \mathrm{O}_{3}$ ceramics attained $81.0 \mathrm{MPa}$. With $\mathrm{SiC}$ ceramics, a slightly lower strength of 65.0 $\mathrm{MPa}$ was observed. With the copper substrate, a shear strength of $84.0 \mathrm{MPa}$ was measured. The highest shear strength was achieved with aluminum - $174.5 \mathrm{MPa}$.

For a more exact identification fractured surfaces in the boundary of $\mathrm{Cu} / \mathrm{Zn} 4 \mathrm{Al}$ and eventually $\mathrm{Al}_{2} \mathrm{O}_{3} / \mathrm{Zn} 4 \mathrm{Al}$ bonds were also identified (Figs. 15, 16).

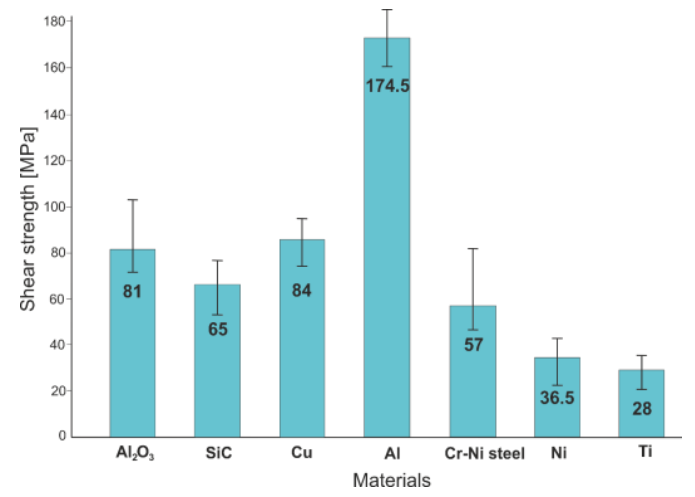

Figure 14

The results of shear strength measurements in joints fabricated by use of $\mathrm{Zn} 4 \mathrm{Al}$ solder 

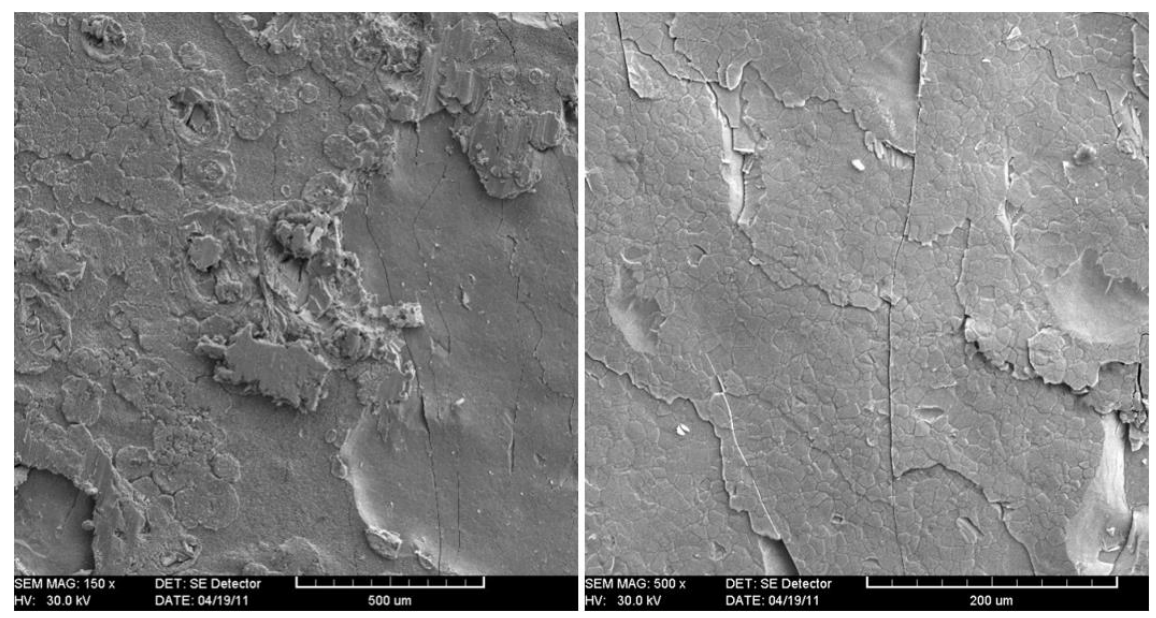

Figure 15

Fractured surface of $\mathrm{Zn} 4 \mathrm{Al} / \mathrm{Cu}$ joint
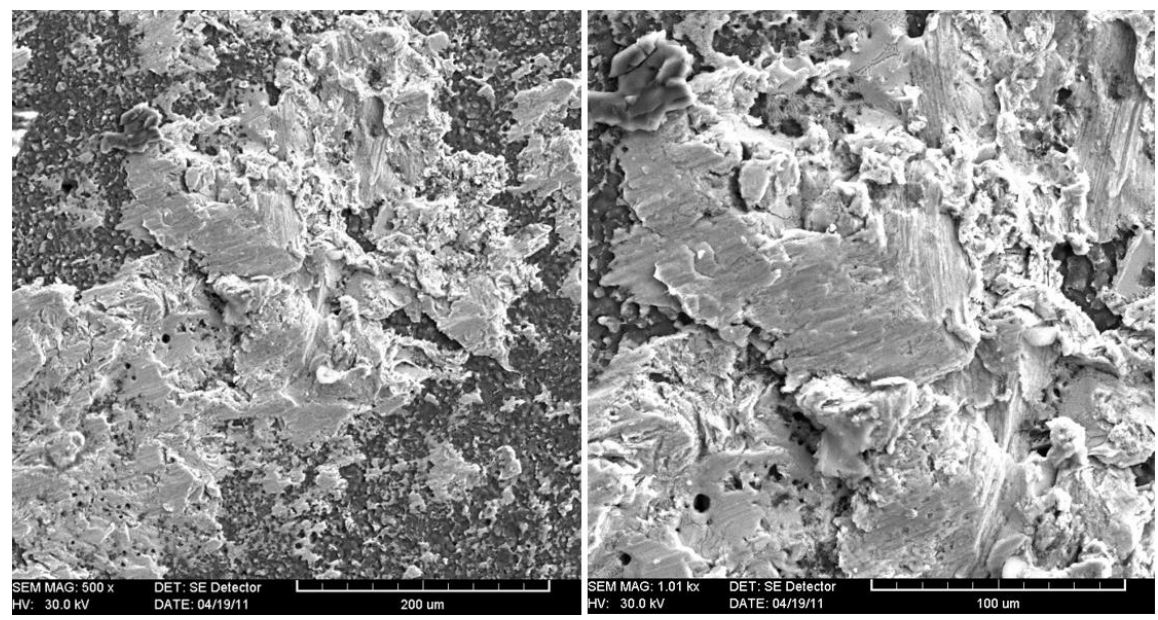

Figure 16

Fractured surface of $\mathrm{Zn} 4 \mathrm{Al} / \mathrm{Al}_{2} \mathrm{O}_{3}$ joint

Formation of a typical ductile failure by shear mechanism was documented in $\mathrm{Cu} / \mathrm{Zn} 4 \mathrm{Al}$ bond (Fig. 15). Fig. 16 shows the fractured surfaces of $\mathrm{Al}_{2} \mathrm{O}_{3} / \mathrm{Zn} 4 \mathrm{Al}$ bonds. Fracture morphology evidently shows a visible motion of the shearing tool with a ductile fracture.

After the shear test, $100 \%$ coverage of $\mathrm{Cu}$ substrate with $\mathrm{Zn} 4 \mathrm{Al}$ solder remained. To the contrary, in the case of $\mathrm{Cu}$ substrate the solder was detached from the ceramic substrate. Partial coverage of $\mathrm{Al}_{2} \mathrm{O}_{3}$ substrate was observed, as documented in Fig. 16. 


\section{Discussion}

The results achieved by direct bonding of ceramic and metallic materials proved that Zn-based solder ensures the wettability at application of ultrasound activation, by which the $\mathrm{Zn} 4 \mathrm{Al}$ solder becomes suitable for practical soldering applications.

For a comparison of results from the shear strength measurement we also present the results from similar studies, while it should be taken into account that different works make use of different test methods, the shape of test pieces and loading rates during testing. They also use different compositions of soldering alloys and soldering parameters.

For example in the case of the application of $\mathrm{Zn}-\mathrm{Al}$ ( $\mathrm{Zn} 14 \mathrm{Al})$ solders in work [8], with $\mathrm{Al}_{2} \mathrm{O}_{3} / \mathrm{Zn} 14 \mathrm{Al} / \mathrm{Cu}$ bonds, a shear strength of $80 \mathrm{MPa}$ was observed at ultrasound power of $200 \mathrm{~W}$. In study [1], the joint of SiC ceramic substrate, soldered with $\mathrm{Zn} 8.5 \mathrm{Al} 1 \mathrm{Mg}$ solder, attained a shear strength of $148.1 \mathrm{MPa}$ at $8 \mathrm{~s}$. of ultrasound action.

In study [2], sapphire was soldered with ultrasound activation by use of Sn10Zn2Al solder. The shear strength of joints attained 43 to $48 \mathrm{MPa}$. More studies dealt with $\mathrm{Sn}-\mathrm{Ag}$-Ti solders. Also, new metallic, ceramic and non-metallic materials were tested.

For example in study [3], the $\mathrm{Al}_{2} \mathrm{O}_{3} / \mathrm{Sn}-\mathrm{Ag}-\mathrm{Ti} / \mathrm{Al}_{2} \mathrm{O}_{3}$ bond showed a shear strength of $24 \mathrm{MPa}$. In work [4], the following strengths were achieved by soldering: $\mathrm{Cu} / \mathrm{Cu}(14.3 \mathrm{MPa})$, ITO/ITO (6.8 MPa) and ITO/Cu (3.4 MPa). Similarly, in study [8], the attained shear strengths of joints were as follows: alumina/alumina (13.5 $\mathrm{MPa}$ ), copper/copper (14.3 MPa) and alumina/copper (10.2 MPa).

\section{Conclusions}

The aim of work was oriented toward the direct bonding of $\mathrm{Al}_{2} \mathrm{O}_{3}, \mathrm{SiC}$ ceramic substrates and a copper substrate. We examined the behavior of $\mathrm{Zn}$-based solder, alloyed with $\mathrm{Al}$, for the wetting of $\mathrm{Al}_{2} \mathrm{O}_{3}$ ceramics and other ceramic materials and the formation of a strong bond with them. Due to this, several analyses of the transition zones for the bonds and the measurements of shear strengths were performed. The following results were achieved:

- DSC analysis revealed that the solder has a smaller melting interval. At a temperature of $380.7^{\circ} \mathrm{C}$, the eutecticum $(\mathrm{Zn}+6 \mathrm{wt} \% \mathrm{Al})$ segregated along the zinc matrix of the solder starts to melt. The solid solution $(\mathrm{Zn})$ attains a fully liquid state at $385.9^{\circ} \mathrm{C}$

- The matrix of $\mathrm{Zn} 4 \mathrm{Al}$ solder is formed of great grains of solid solution ( $\mathrm{Zn}$ ) with a $\mathrm{Zn}$ concentration of $98.68 \mathrm{wt} \%$. A fine eutecticum, formed of solid solutions $(\mathrm{Zn})+(\mathrm{Al})$, is segregated along the grain boundaries. 
- In $\mathrm{SiC} / \mathrm{Zn} 4 \mathrm{Al}$ bond boundary a transition zone was formed up to $70 \mu \mathrm{m}$ in width, where increased amounts, mainly of carbidic and silicon particles, were identified.

- No distinct transition layer was observed in the $\mathrm{Al}_{2} \mathrm{O}_{3} / \mathrm{Zn} 4 \mathrm{Al}$ bond boundary. The character of solder matrix in this boundary is unchanged. The $\mathrm{Al}_{2} \mathrm{O}_{3} / \mathrm{Zn} 4 \mathrm{Al}$ bond is formed due to the adhesion of solder with $\mathrm{Al}_{2} \mathrm{O}_{3}$ ceramics.

- A wide zone of two new intermetallic phases was formed on the $\mathrm{Cu} / \mathrm{Zn} 4 \mathrm{Al}$ boundary (Fig. 14), where $\mathrm{CuZn}_{4}$ and $\mathrm{Cu}_{5} \mathrm{Zn}_{8}$ phases were identified.

- The shear strength of 81.0 MPa was obtained with $\mathrm{Al}_{2} \mathrm{O}_{3}$ ceramics. With $\mathrm{SiC}$ ceramics, a slightly lower strength of $65.0 \mathrm{MPa}$ was observed. With copper substrate, a shear strength of $84.0 \mathrm{MPa}$ was measured. The highest shear strength was achieved with aluminum at $174.5 \mathrm{MPa}$.

After the shear test, $100 \%$ coverage of $\mathrm{Cu}$ substrate with $\mathrm{Zn} 4 \mathrm{Al}$ solder remained. In contrast, for the case of the $\mathrm{Cu}$ substrate, the solder was detached from the ceramic substrate, whereas, partial coverage of $\mathrm{Al}_{2} \mathrm{O}_{3}$ substrate was observed.

\section{Acknowledgement}

The contribution was prepared with the support of APVV-0023-12: Research of new soldering alloys for fluxless soldering with application of beam technologies and ultrasound and VEGA 1/0455/14: Research of modified solders for fluxless soldering of metallic and ceramic materials. The authors thank Ing. Marián Drienovský, $\mathrm{PhD}$. for DSC analysis; doc. Ing. Maroš Martinkovič, $\mathrm{PhD}$. for shear strength measurements and Ing. Ivona Černičková, PhD. for EDX analysis.

\section{References}

[1] Chen, X., Yan, J., Ren, S., et al., Microstructure, Mechanical Properties, and Bonding Mechanism of Ultrasonic-assisted Brazed Joints of SiC Ceramics with ZnAlMg Filler Metals in Air. In Ceramics International, Vol. 40, 2014, pp. 683-689

[2] Cui, W., Yan, J., Dai, Y., Li, D., Building a Nano-Crystalline $\alpha$-alumina Layer at a Liquid Metal/Sapphire Interface by Ultrasound. In Ultrasonics Sonochemistry, Vol. 22, 2015, pp. 108-112

[3] Koleňák, R., Šebo, P., Provazník, M., Koleňáková, M., Ulrich, K. Shear Strength and Wettability of Active $\mathrm{Sn} 3.5 \mathrm{Ag} 4 \mathrm{Ti}(\mathrm{Ce}, \mathrm{Ga})$ Solder on $\mathrm{Al}_{2} \mathrm{O}_{3}$ Ceramics. In Materials and Design, Vol. 32, 2011, pp. 3997-4003

[4] Chang, S. Y., Tsao, L. C., Chiang, M. J., et al., Active Soldering of Indium Tin Oxide (ITO) With $\mathrm{Cu}$ in Air Using an Sn3.5Ag4Ti(Ce,Ga) Filler. In Journal of Materials Engineering and Performance, Vol. 12, No. 4, 2003, pp. 383-390 
[5] Chang, S. Y., Chuang, T. H., Yang, C. L., Low Temperature Bonding of Alumina/Alumina and Alumina/Copper in Air Using Sn3.5Ag4Ti(Ce,Ga) Filler. In Journal of Electronic Materials, Vol. 36, No. 9, 2007, pp. 11931199

[6] M. Martinkovič [patent inventor], R. Koleňák [patent inventor]: The Form on the Production of Experimental Soldered Joint - Patent 288180. Industrial Property Office of the Slovak Republic [patentee]. Date of patent accordance: 12.02 .2014

[7] Murray, J. L. The Al-Zn (Aluminium-Zinc) System. In Bulletin of Alloy Phase Diagrams, Vol. 4, Is. 1, 1983, pp. 55-73

[8] Ji, H., Chen, H., Li, M., Microstructures and Properties of Alumina/Copper Joints Fabricated by Ultrasonic-assisted Brazing for Replacing DBC in Power Electronics Packaging. In $15^{\text {th }}$ International Conference on Electronic Packaging Technology, IEEE, 2014, pp. 1291-1295 